\title{
Mathematical Modeling, Moisture Diffusion and Color Quality in Intermittent Microwave Drying of Organic and Conventional Sweet Red Peppers
}

\author{
Aysel Arslan, Yurtsever Soysal *(D) and Muharrem Keskin (D) \\ Department of Biosystems Engineering, Faculty of Agriculture, Hatay Mustafa Kemal University, \\ 31030 Antakya, Hatay, Turkey; aysel.arslan.hty@gmail.com (A.A.); mkeskinhatay@gmail.com (M.K.) \\ * Correspondence: yurtsever.soysal@gmail.com; Tel.: +90-326-245-5829
}

Received: 24 June 2020; Accepted: 9 July 2020; Published: 13 July 2020

check for updates

\begin{abstract}
The aims of this research were to evaluate the influence of intermittent microwave drying on the moisture diffusion and color qualities of organically and conventionally grown sweet red peppers and mathematically express drying kinetic data. Pepper samples of $150 \mathrm{~g}$ were dried at 150,300 and $450 \mathrm{~W}$ using a microwave oven. Results showed that intermittent microwave drying at $450 \mathrm{~W}$ occurred mainly in the falling rate period, whereas drying at lower powers resulted in relatively longer constant rate periods for both peppers types. The Midilli model provided the best fit for all data. The moisture diffusivity $\left(\mathrm{D}_{\text {eff }}\right)$ values of organic and conventional samples ranged from $59.69 \times 10^{-10}$ to $182.01 \times 10^{-10} \mathrm{~m}^{2} \mathrm{~s}^{-1}$ and from $59.11 \times 10^{-10}$ to $181.01 \times 10^{-10} \mathrm{~m}^{2} \mathrm{~s}^{-1}$, respectively, and the difference was insignificant. The pre-exponential factor for the Arrhenius equation $\left(\mathrm{D}_{0}\right)$ and activation energy $\left(E_{a}\right)$ values were almost identical for both product types. Overall, organic or conventional growing did not alter the structural features related to the heat transfer properties. Intermittent microwave drying at 150 and $300 \mathrm{~W}$ for organic peppers and $150 \mathrm{~W}$ for conventional peppers gave the highest $\Delta \mathrm{L}^{*}, \Delta \mathrm{a}^{*}$ and $\mathrm{a}^{*} / \mathrm{b}^{*}$ values, producing the most bright and red pepper powders. Thus, these treatments can be used to produce higher color quality powders.
\end{abstract}

Keywords: organic vegetable; post-harvest processing; drying rate; quality; activation energy

\section{Introduction}

Organic farming has been gaining importance both in the world ( 31.5 million to 69.8 million ha increase in 2007-2017) and in Turkey (0.17 million to 0.54 million ha increase in 2007-2017), which ranked 17th in the world in terms of the amount of organic farmland [1,2]. Organic farming offers pesticide residue-free, healthy, and tasty products [3]. Since organic fruits and vegetables are not subjected to synthetic chemical pesticides and fertilizers, they use higher amounts of metabolic energy to produce secondary plant metabolites such as antioxidants and phenolic compounds [4]. It was reported that the secondary metabolites in organic fruits and vegetables were $12 \%$ higher than in conventional samples [5]. Hence, growing conditions of the product could affect the phytochemical content, structure, taste and aroma. It was mentioned that organic products have higher antioxidant activity, higher levels (18-69\%) of antioxidants, phenolic compounds and other plant secondary metabolites and also, lower amounts of agrochemical residues $(75 \%)$ and cadmium (48\%), which all related to chronic and neurodegenerative diseases and certain cancers [6].

Pepper (Capsicum annuum L.) is a very important source of food, medicinal and industrial products as a cheap source of vitamins, fibers and minerals [7]. It is consumed as fresh or dried and is also used for the production of spices, pastes, natural colorants, soups, sauces and oleoresin [8]. The total pepper production was about 36.1 million tonnes in the world and 2.6 million tonnes in Turkey [9]. Organic pepper production is important, with about 5558 tonnes (in 2018) in Turkey [10]. 
Nowadays, the demand for dried organic products has increased remarkably with the spectacular trends in the healthier food market. Pepper fruits can quickly rot after harvest due to the high initial moisture content being up to $90 \%$ wet-based [8]. Hence, fresh fruits, like peppers, are highly perishable products and are generally dried to increase their shelf life and make them accessible to consumers during the whole year. Various drying practices such as sun, hot-air, infrared and microwave drying are applied to preserve this perishable product without impairing its quality such as color, valuable vitamins, minerals and nutrients. Though sun and hot air drying are still the most common methods to produce red pepper flakes and powdered spices, the drying process in both methods takes quite a long time and associated quality losses occur [11-13]. Use of microwaves to shorten the drying time and protect the quality of the final dried products is a promising alternative in drying of perishable agricultural products like pepper. Since microwaves affect the product as a whole, heating up the product volumetrically and pumping up the moisture from inside to outside, it eliminates case hardening and yields increased diffusion rates [14-16]. Nevertheless, it is well known that the continuous application of microwaves during the drying process could lead to overheating and uneven heating problems. Intermittent application of microwave energy can eliminate these drawbacks $[17,18]$. As intermittent application of microwave energy provides the rest time to allow moisture redistribution by limiting temperature increase, it results in higher energy efficiency and product quality [19-22]. Various studies signified the superiority of intermittent application of microwaves for various vegetables and fruits such as strawberry [23], banana [24], red pepper [8,25], carrot [26], oregano [27], fig [28], pumpkin [29] and apple [30].

Only very few studies have been reported comparing the effects of drying on organically or conventionally produced crops [31,32]. The first study [31] concentrated on the effects of freeze drying, air-drying and flash freezing on the total amount of ascorbic acid and phenolics of strawberry, marionberry and corn produced using conventional, organic and sustainable production practices, but it contained no information on the drying characteristics of the products. The second study [32] was related to the influence of air and freeze drying on the phytochemical content and moisture diffusivity of conventional and organic berries. No significant differences between the phytochemical contents in fresh conventional and organic berries were found. They stated that the air drying resulted in considerable changes in phytochemical compounds in both conventionally and organically grown berries, whereas freeze drying increased the phytochemicals and in some cases, it increased the phytochemicals contents as compared to air drying.

Even if there is an increasing demand for organic products due to the consumer preference for healthier and tastier foods, studies on the comparison of drying kinetics and color parameters of organic and conventional products have been very limited. Mathematical models could be useful to estimate the moisture and temperature of the product during the drying process and the drying capacity of the system. Therefore, the aim of this work was to compare the drying kinetics, mathematical models, moisture diffusion characteristics and color qualities of the organically and conventionally grown sweet red peppers dried by intermittent microwave drying.

\section{Materials and Methods}

\subsection{Pepper Samples}

Sweet red peppers (Capia pepper, Diyar F1 cultivar) produced in organic and conventional farming methods under greenhouse conditions were obtained directly from farmers located near Erdemli, Mersin, Turkey (36.6115 N, 34.2624 E). This type of pepper is intensively cultivated and consumed in Turkey. The peppers were hand harvested in the red stage and stored at $+4^{\circ} \mathrm{C}$ for one day, and then, the drying experiments were started and completed in ten days. The moisture contents of the pepper slices were determined by using a standard oven method $\left(103^{\circ} \mathrm{C}\right.$ for $\left.24 \mathrm{~h}\right)$. Before each drying experiment, three samples were utilized for moisture content determination. The average initial 
moisture contents of the organic and conventional pepper samples were $91.65 \pm 0.20 \%$ (wet basis) and $92.06 \pm 0.27 \%$ (wet basis), respectively.

\subsection{Intermittent Microwave Drying (IMD)}

A lab-scale microwave oven (MD 1605, Beko, Istanbul, Turkey) with a maximum rated power of $900 \mathrm{~W}$ at $2.45 \mathrm{GHz}$ was utilized in the drying experiments. The size of the microwave oven cavity was about $22 \times 35 \times 33 \mathrm{~cm}$. The microwave oven's actual power was calculated as $736 \mathrm{~W}$ by using the IMPI-2L test [33]. The experiments were carried out at three power levels (150, 300 and $450 \mathrm{~W})$ by changing the microwave on and off times ( $\mathrm{T}_{\text {on }}$ and $\left.\mathrm{T}_{\text {off }}\right)$ as controlled by a programmable logic controller (PLC) (Table 1). The mass of the microwave turntable with the shredded pepper sample and air temperature inside the microwave cavity were recorded at every minute during the drying process. An axial fan was used to aspirate moist air from the drying chamber at about $1.5 \mathrm{~ms}^{-1}$ airflow speed. The peppers were washed with tap water, rinsed with distilled water, and then, they were dripped and shredded at a thickness of about $1.43 \pm 0.09 \mathrm{~mm}$. In each drying process, about $150 \mathrm{~g}$ of shredded pepper sample was distributed evenly and homogeneously in a layer with a thickness of $7.6 \pm 0.07 \mathrm{~mm}$ on a glass tray with a $30 \mathrm{~cm}$ diameter (Figure 1). All drying experiments were conducted in an acclimatized laboratory at room temperature. Moisture loss from the material was recorded at one minute intervals, with an accuracy of $0.01 \mathrm{~g}$. All experiments were ended when the pepper samples

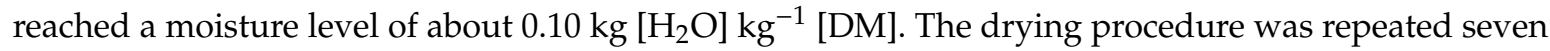
times at each of the three microwave power levels for both product types (organic and conventional) giving a total 42 drying experiments $(3 \times 7 \times 2=42)$.

Table 1. Applied intermittent microwave power and related parameters used in the drying experiments of organic and conventional red peppers.

\begin{tabular}{|c|c|c|c|c|c|c|c|c|}
\hline Products & $\begin{array}{c}\text { AIMP } \\
\text { (W) }\end{array}$ & $\begin{array}{l}\text { IM } \\
(\mathrm{g})\end{array}$ & $\begin{array}{c}\text { SIMP } \\
\left(W^{-1}\right)\end{array}$ & $\mathbf{P P} *$ & $\begin{array}{l}T_{\text {on }} \\
\text { (s) }\end{array}$ & $\begin{array}{c}T_{\text {off }} \\
(s)\end{array}$ & $\begin{array}{c}\text { PR ** } \\
(-)\end{array}$ & $\begin{array}{r}\mathrm{MCT} \\
\left({ }^{\circ} \mathrm{C}\right)\end{array}$ \\
\hline \multirow{3}{*}{ Organic red pepper } & 150 & 150.09 & 1.0 & 0.20 & 15 & 59 & 4.93 & 45.0 \\
\hline & 300 & 150.08 & 2.0 & 0.41 & 15 & 22 & 2.47 & 58.7 \\
\hline & 450 & 150.19 & 3.0 & 0.61 & 15 & 10 & 1.67 & 68.3 \\
\hline \multirow{3}{*}{ Conventional red pepper } & 150 & 150.12 & 1.0 & 0.20 & 15 & 59 & 4.93 & 46.9 \\
\hline & 300 & 150.10 & 2.0 & 0.41 & 15 & 22 & 2.47 & 63.9 \\
\hline & 450 & 150.14 & 3.0 & 0.61 & 15 & 10 & 1.67 & 72.8 \\
\hline
\end{tabular}

AIMP-Applied intermittent microwave power; IM-Initial mean mass; SIMP—Specific intermittent microwave power; $\mathrm{PP}^{*}$-Power proportion; $\mathrm{T}_{\text {on }}$ - On time; $\mathrm{T}_{\text {off }}$-Off time; $\mathrm{PR}-$ Pulse ratio; MCT-Mean cavity temperature; ${ }^{*} \mathrm{PP}$ was computed by dividing the AIMP by microwave oven's actual power $(736 \mathrm{~W})$; ${ }^{* *} \mathrm{PR}=\left(\mathrm{T}_{\text {on }}+\mathrm{T}_{\text {off }}\right) / \mathrm{T}_{\text {on }}[26]$.

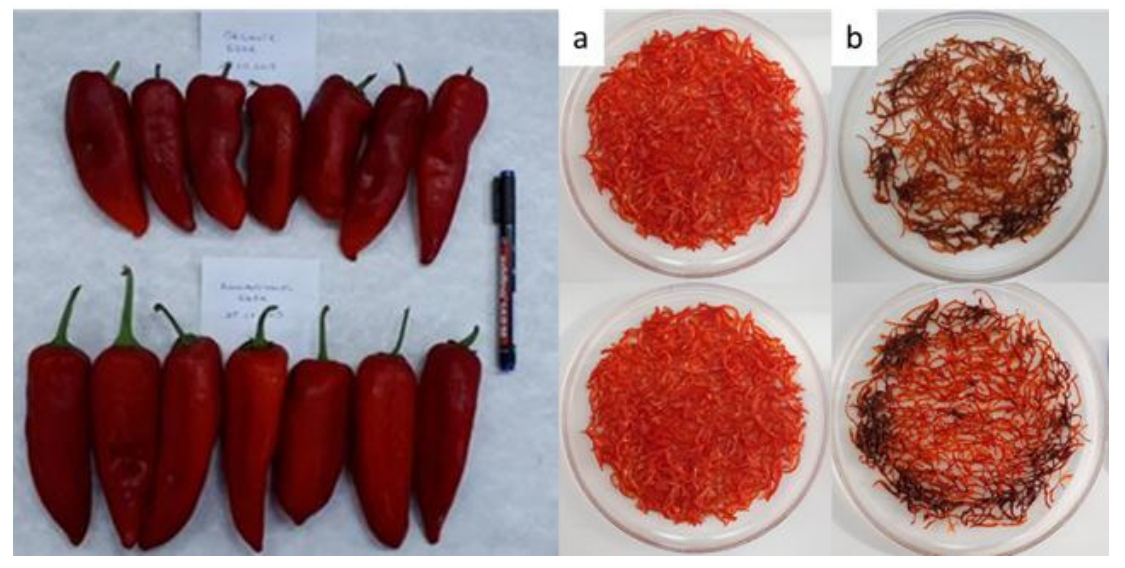

Figure 1. Whole organic (above) and conventional (below) sweet red peppers (left); (a)—fresh organic (above) and conventional (below) pepper shreds; (b)—dried organic (above) and conventional (below) pepper shreds. 


\subsection{Mathematical Modeling of Drying Curves}

The data were fitted to various drying models to determine the best fitting drying equation. A total of eleven drying models were appraised in the study (Table 2). The equilibrium moisture content $\left(M_{e}\right)$ was assumed to be zero and therefore, the moisture ratio (MR) was simplified to $M / M_{0}$ instead of $\left(\mathrm{M}-\mathrm{M}_{\mathrm{e}}\right) /\left(\mathrm{M}_{0}-\mathrm{M}_{\mathrm{e}}\right)$, where $\mathrm{M}_{\mathrm{e}}$ is the equilibrium moisture content $\left(\mathrm{kg}\left[\mathrm{H}_{2} \mathrm{O}\right] \mathrm{kg}^{-1}[\mathrm{DM}]\right), \mathrm{M}$ is the moisture content at any time during drying $\left(\mathrm{kg}\left[\mathrm{H}_{2} \mathrm{O}\right] \mathrm{kg}^{-1}[\mathrm{DM}]\right)$ and $\mathrm{M}_{0}$ is the initial moisture $\left(\mathrm{kg}\left[\mathrm{H}_{2} \mathrm{O}\right] \mathrm{kg}^{-1}[\mathrm{DM}]\right)[12,34]$.

Table 2. Mathematical models for the drying curves of organic and conventional red peppers used in the study.

\begin{tabular}{ccc}
\hline Model Name & Model Equation * & References \\
\hline 1. Newton & $\mathrm{MR}=\exp (-\mathrm{kt})$ & {$[35]$} \\
2. Page & $\mathrm{MR}=\mathrm{a} \exp \left(-\mathrm{kt}^{\mathrm{n}}\right)$ & {$[36]$} \\
3. Henderson and Pabis & $\mathrm{MR}=\mathrm{a} \exp (-\mathrm{kt})$ & {$[35]$} \\
4. Logarithmic & $\mathrm{MR}=\mathrm{a} \exp (-\mathrm{kt})+\mathrm{b}$ & {$[37]$} \\
5. Midilli et al. & $\mathrm{MR}=\mathrm{a} \exp \left(-\mathrm{kt}^{\mathrm{n}}\right)+\mathrm{bt}$ & {$[38]$} \\
6. Wang and Singh & $\mathrm{MR}=1+\mathrm{at}+\mathrm{bt}^{2}$ & {$[40]$} \\
7. Logistic & $\mathrm{MR}=\mathrm{b} /(1+\mathrm{a} \exp (\mathrm{kt}))$ & {$[40]$} \\
8. Two term & $\mathrm{MR}=\mathrm{a} \exp (-\mathrm{kt})+\mathrm{b} \exp \left(-\mathrm{k}_{1} \mathrm{t}\right)$ & {$[41]$} \\
9. Verma et al. & $\mathrm{MR}=\mathrm{a} \exp (-\mathrm{kt})+(1-\mathrm{a}) \exp (-\mathrm{bt})$ & {$[12]$} \\
10. Two term exponential & $\mathrm{MR}=\mathrm{a} \exp (-\mathrm{kt})+(1-\mathrm{a}) \exp (-\mathrm{kat})$ & {$[12]$} \\
11. Diffusion approximation & $\mathrm{MR}=\mathrm{a} \exp (-\mathrm{kt})+(1-\mathrm{a}) \exp (-\mathrm{kbt})$ &
\end{tabular}

* MR-moisture ratio; $\mathrm{k}$ and $\mathrm{k}_{1}$ —drying coefficients; $\mathrm{n}$-exponent; $\mathrm{t}$-time in minutes; $\mathrm{a}$ and $\mathrm{b}$-model coefficients.

Nonlinear regression analyses for these models were carried out in the SigmaPlot program (Version 12; Systat Software, San Jose, CA, USA). The coefficient of determination $\left(\mathrm{R}^{2}\right)$, standard error of estimate (SEE) and residual sum of squares (RSS) were utilized to select the best equation. These parameters were computed as follows:

$$
\begin{aligned}
\mathrm{RSS} & =\sum_{\mathrm{j}=1}^{\mathrm{N}}\left(\mathrm{MR}_{\text {exp }, \mathrm{i}}-\mathrm{MR}_{\text {pre }, \mathrm{i}}\right)^{2} \\
\mathrm{SEE} & =\left[\frac{\sum_{\mathrm{j}=1}^{\mathrm{N}}\left(\mathrm{MR}_{\text {exp }, \mathrm{i}}-\mathrm{MR}_{\text {pre, }, \mathrm{i}}\right)^{2}}{\mathrm{~N}-2}\right]^{0.5}
\end{aligned}
$$

where $\mathrm{MR}_{\text {exp,i }}$ is the ith experimental moisture ratio, $\mathrm{MR}_{\text {pre, }}$ is the ith estimated moisture ratio and $\mathrm{N}$ is the number of data.

\subsection{Calculation of the Effective Moisture Diffusivity $\left(D_{\text {eff }}\right)$ and Activation Energy $\left(E_{a}\right)$}

The effective moisture diffusivity $\left(D_{\text {eff }}\right)$ values were interpreted by using Fick's second diffusion equation. The general solution of Equation (3) for slab geometry with the assumptions of diffused moisture migration, insignificant shrinkage, constant diffusion coefficients and temperature is given below [42]:

$$
\mathrm{MR}=\frac{\mathrm{M}-\mathrm{M}_{\mathrm{e}}}{\mathrm{M}_{0}-\mathrm{M}_{\mathrm{e}}}=\frac{8}{\pi^{2}} \sum_{\mathrm{i}=0}^{\infty} \frac{1}{(2 \mathrm{i}+1)^{2}} \exp \left[\frac{(2 \mathrm{i}+1)^{2} \pi^{2} \mathrm{D}_{\mathrm{eff}} \mathrm{t}}{4 \mathrm{~L}^{2}}\right]
$$

where MR is the moisture ratio, $\mathrm{M}$ is the moisture content at any time during drying $\left(\mathrm{kg}^{2}\left[\mathrm{H}_{2} \mathrm{O}\right]\right.$ $\left.\mathrm{kg}^{-1}[\mathrm{DM}]\right), \mathrm{M}_{\mathrm{e}}$ is the equilibrium moisture content $\left(\mathrm{kg}\left[\mathrm{H}_{2} \mathrm{O}\right] \mathrm{kg}^{-1}[\mathrm{DM}]\right), \mathrm{M}_{0}$ is the initial moisture 
content $\left(\mathrm{kg}\left[\mathrm{H}_{2} \mathrm{O}\right] \mathrm{kg}^{-1}[\mathrm{DM}]\right), \mathrm{D}_{\text {eff }}$ is the effective moisture diffusivity $\left(\mathrm{m}^{2} \mathrm{~s}^{-1}\right), \mathrm{L}$ is the half thickness of the samples $(\mathrm{m}), \mathrm{i}$ is a positive integer and $\mathrm{t}$ is time (s).

For the long drying process, Equation (3) can be further simplified as follows [43]:

$$
\ln (\mathrm{MR})=\frac{8}{\pi^{2}}-\frac{\pi^{2} \mathrm{D}_{\text {eff }}}{4 \mathrm{~L}^{2}} \mathrm{t}
$$

The $D_{\text {eff }}$ values were calculated by plotting experimental $\ln (\mathrm{MR})$ data against drying time, so the plot provides a straight line with a slope as $\mathrm{K}=\pi^{2} \mathrm{D}_{\text {eff }} / 4 \mathrm{~L}^{2}$.

In this study, the dependency of the effective moisture diffusivity $\left(\mathrm{D}_{\text {eff }}\right)$ on the ratio of applied microwave power to fresh sample mass were characterized with an Arrhenius-type exponential model Equation (5) derived by [44]:

$$
\mathrm{D}_{\text {eff }}=\mathrm{D}_{0} \exp \left(-\mathrm{E}_{\mathrm{a}} \cdot \mathrm{m} / \mathrm{P}_{\mathrm{a}}\right)
$$

where $D_{\text {eff }}$ is the effective moisture diffusivity $\left(\mathrm{m}^{2} \mathrm{~s}^{-1}\right), \mathrm{D}_{0}\left(\mathrm{~m}^{2} \mathrm{~s}^{-1}\right)$ is a pre-exponential factor, $E_{\mathrm{a}}$ is the activation energy $\left(\mathrm{Wg}^{-1}\right), \mathrm{P}_{\mathrm{a}}$ is the applied microwave power $(\mathrm{W})$ and $\mathrm{m}$ is the fresh sample mass $(\mathrm{g})$.

Then, the $E_{a}$ was computed from the slope of the Equation (5) by plotting $\ln \left(D_{\text {eff }}\right)$ versus $m / P_{a}$.

\subsection{Color Analysis}

The color of the fresh and dried-powdered red peppers was measured with a hand-held chromameter (Minolta CR-400, Osaka, Japan). The CIE L*a*b* color model was used. The chromameter was utilized with illuminant $C$ standard and calibrated using its white reflector plate. The color in the $\mathrm{L}^{*} \mathrm{a}^{*} \mathrm{~b}^{*}$ model is expressed in three dimensions and the meaning of each parameter is as follow: $\mathrm{L}^{*}$ - Brightness of the color (0-black; 100-white), a* - Redness-greenness (-60-green; +60-red), $b^{*}$-Yellowness-blueness (-60-blue; +60 -yellow). In measuring the color of the samples, ground material measurement apparatus was used. Color change of the material was evaluated by using the redness to yellowness ratio $\left(a^{*} / b^{*}\right)$, total color difference $\left(\Delta \mathrm{E}^{*}\right)$ and color difference values for all three parameters $\left(\Delta \mathrm{L}^{*}, \Delta \mathrm{a}^{*}\right.$, and $\left.\Delta \mathrm{b}^{*}\right)$ :

$$
\begin{gathered}
\Delta \mathrm{L}^{*}=\mathrm{L}_{\mathrm{d}}^{*}-\mathrm{L}_{\mathrm{f}}^{*} \\
\Delta \mathrm{a}^{*}=\mathrm{a}_{\mathrm{d}}^{*}-\mathrm{a}_{\mathrm{f}}^{*} \\
\Delta \mathrm{b}^{*}=\mathrm{b}_{\mathrm{d}}^{*}-\mathrm{b}_{\mathrm{f}}^{*} \\
\Delta \mathrm{E}^{*}=\left[\Delta \mathrm{L}^{* 2}+\Delta \mathrm{a}^{* 2}+\Delta \mathrm{b}^{* 2}\right]^{0.5}
\end{gathered}
$$

where $d$ and $f$ refer to the dried and fresh products, respectively.

\subsection{Statistical Analysis}

Seven fresh samples and 42 dried-powdered samples (three power levels of 150, 300 and $450 \mathrm{~W}$ multiplied by seven drying experiments and two production methods) for both organic and conventional red sweet peppers were included in the data analysis. The effect of the drying temperatures on the color of the dried organic and conventional red pepper powder samples was statistically evaluated with a statistic software (SPPS, v.17, IBM, NY, USA) using one-way analysis of variance (ANOVA) and the means were compared with Duncan's test $(p<0.05)$.

\section{Results and Discussion}

\subsection{Drying Kinetics}

Change of moisture ratio (MR) in intermittent microwave drying of organic and conventional sweet red pepper shreds is presented in Figure 2. The moisture content of the samples decreased to

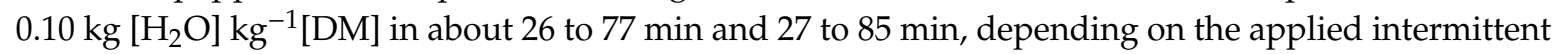
microwave power for organic and conventional sweet red pepper shreds, respectively (Figure 2, Table 3). 
It was found that increasing the applied microwave power diminished the drying time significantly $(p<0.05)$. Compared to organic peppers, drying time of the conventional pepper shreds lasted 1 to 8 min longer. Except $150 \mathrm{~W}$, no substantial difference was found between the drying times of organic and conventional pepper samples dried at 300 and $450 \mathrm{~W}$ power levels. Mean cavity temperature was found to be higher in conventional red pepper, probably due to the longer drying time (Table 1).
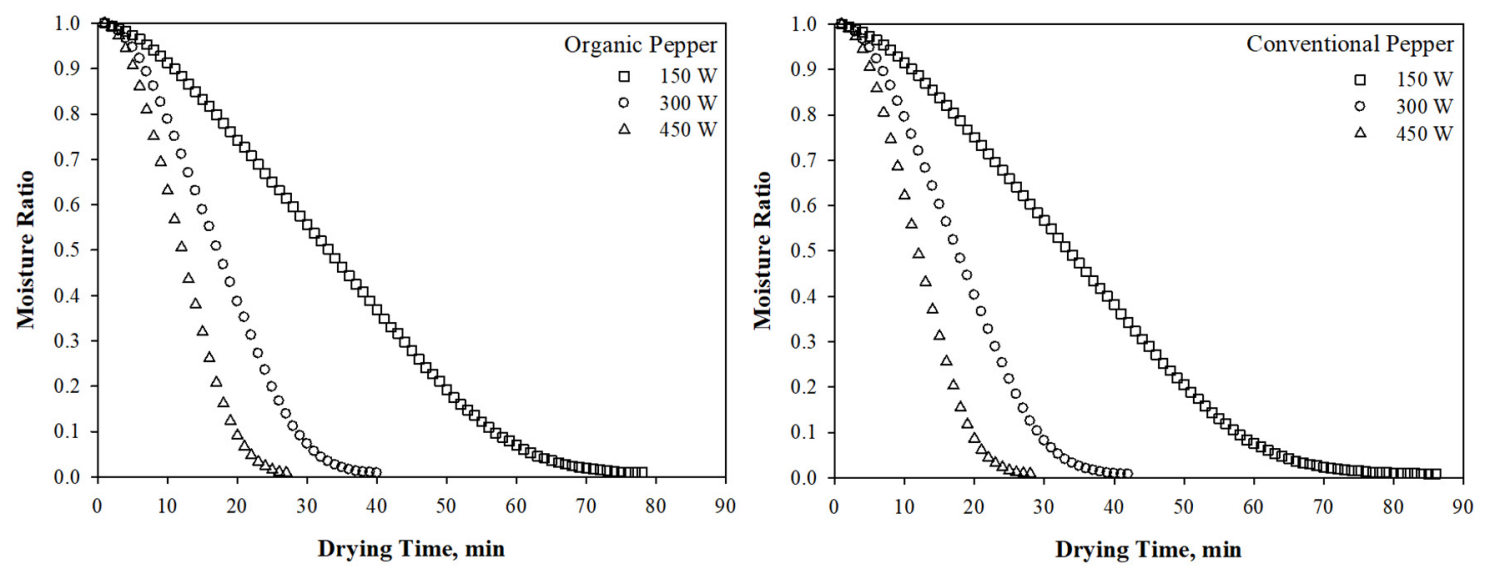

Figure 2. Change of moisture ratio in intermittent microwave drying of organic and conventional sweet red pepper shreds.

Table 3. Effect of applied microwave powers on the mean drying time of organic and conventional sweet red pepper samples.

\begin{tabular}{ccc}
\hline & \multicolumn{2}{c}{ Drying Time * $($ min) } \\
\cline { 2 - 3 } Intermittent Microwave Power (W) & $\begin{array}{c}\text { Organic } \\
\text { Red Pepper }\end{array}$ & $\begin{array}{c}\text { Conventional } \\
\text { Red Pepper }\end{array}$ \\
\hline 150 & $77.14 \pm 3.02^{\mathrm{c}}$ & $84.57 \pm 3.36^{\mathrm{d}}$ \\
300 & $38.57 \pm 2.76^{\mathrm{b}}$ & $40.71 \pm 1.80^{\mathrm{b}}$ \\
450 & $25.57 \pm 0.79^{\mathrm{a}}$ & $27.00 \pm 1.63^{\mathrm{a}}$ \\
\hline
\end{tabular}

* Different letters (a, b, c, d) specify significant differences $(p<0.05)$.

It is clearly seen that the drying rate was in an increasing trend at the early stage of the drying process (Figure 3). At 150 and $300 \mathrm{~W}$, a relatively longer constant drying rate period was observed (no constant drying rate period at $450 \mathrm{~W}$ ). In addition, the drying rate was in a decreasing trend (falling rate period) at the final stage of the drying process. After a short heating process during the early stage of drying, intermittent microwave drying process at $450 \mathrm{~W}\left(\mathrm{PR}=1.67\right.$; SIMP $\left.=3.0 \mathrm{~W} \mathrm{~g}^{-1}\right)$ for organic and conventional pepper shreds, the drying rate increased to a maximum and then, decreased without a distinct constant drying rate period. On the contrary, a relatively long constant rate period was visible at lower specific powers $\left(1.0\right.$ and $2.0 \mathrm{~W} \mathrm{~g}^{-1}$ ), which corresponds to higher PR levels (PR $=4.93$ for $150 \mathrm{~W}$ and $\mathrm{PR}=2.47$ for $300 \mathrm{~W}$ ). As PR increased, the length of the constant drying rate period increased (Figure 3). This phenomenon could be due to the longer MW power off time ( $\mathrm{T}_{\text {off }}$ ), which provided longer rest time for better moisture and temperature distribution inside the product until the following $\mathrm{MW}$ on time $\left(\mathrm{T}_{\mathrm{on}}\right)$. These findings are supported by various intermittent microwave drying studies $[19,22,23,26,45,46]$. 

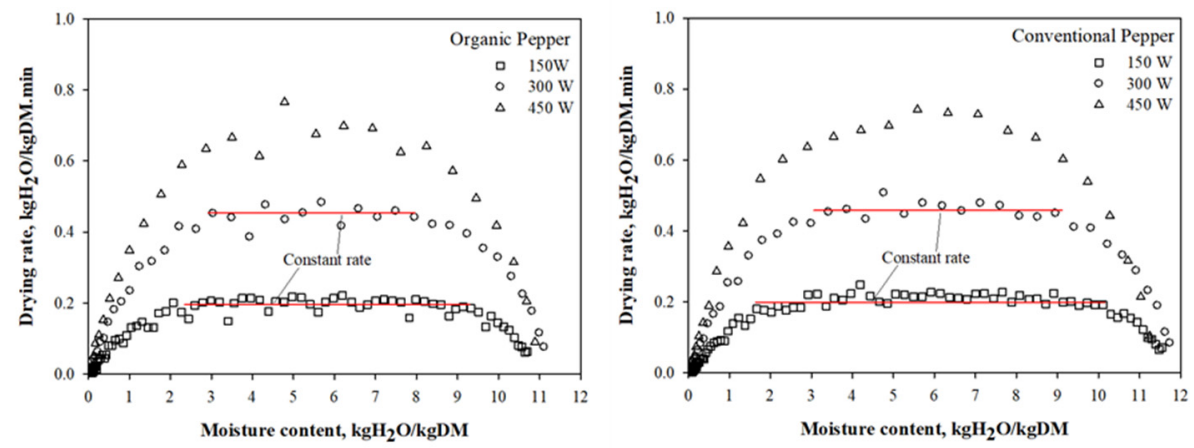

Figure 3. Change of drying rate as a function of moisture content for intermittent microwave drying of organic and conventional sweet red pepper shreds.

\subsection{Modeling of Drying Curves}

The experimental moisture contents on a dry weight basis at different times during the intermittent microwave drying (IMD) process were transformed to moisture ratio (MR) values and fitted against the drying time. Fitting ability of eleven thin layer drying models were assessed based on the parameters of the standard error of estimates (SEE), the residual sum of squares (RSS), and the coefficients of determination $\left(\mathrm{R}^{2}\right)$ (Table 4). The most suitable model for the microwave drying kinetics of sweet red pepper shreds was determined based on the highest $R^{2}$ value and lowest RSS and SEE values. Among the eleven drying models tested in the study, the Midilli model (Model 5) presented the best fit for all drying data points for organic and conventional peppers, with values for the $\mathrm{R}^{2}$ greater than 0.9986, the SEE of lower than 0.0135 and the RSS of lower than 0.0148 (Table 4). The drying coefficient $k$ had higher values as a result of the increase in applied intermittent microwave power (Table 5). These findings were consistent with the drying rate data that followed a similar trajectory. Validation of the Midilli model was depicted in Figure 4, which shows predicted data closely positioned on and near the $1: 1$ ratio straight line.

Table 4. Fitting ability of eleven drying models for the intermittent microwave drying of organic and conventional sweet red peppers.

\begin{tabular}{|c|c|c|c|c|c|c|c|c|c|c|}
\hline \multirow{2}{*}{$\begin{array}{l}\text { Product } \\
\text { Type }\end{array}$} & \multirow{2}{*}{$\begin{array}{l}\text { Model } \\
\text { No }\end{array}$} & \multicolumn{3}{|c|}{$150 \mathrm{~W}$} & \multicolumn{3}{|c|}{$300 \mathrm{~W}$} & \multicolumn{3}{|c|}{$450 \mathrm{~W}$} \\
\hline & & $\mathbf{R}^{2}$ & SEE & RSS & $\mathbf{R}^{2}$ & SEE & RSS & $\mathbf{R}^{2}$ & SEE & RSS \\
\hline \multirow{11}{*}{$\begin{array}{l}\text { Organic red } \\
\text { pepper }\end{array}$} & 1 & 0.8967 & 0.1108 & 0.9446 & 0.8847 & 0.1221 & 0.5818 & 0.8795 & 0.1272 & 0.4208 \\
\hline & 2 & 0.9968 & 0.0198 & 0.0297 & 0.9984 & 0.0147 & 0.0082 & 0.9992 & 0.0105 & 0.0027 \\
\hline & 3 & 0.9358 & 0.0879 & 0.5869 & 0.9274 & 0.0982 & 0.3661 & 0.9221 & 0.1043 & 0.2718 \\
\hline & 4 & 0.9875 & 0.0390 & 0.1139 & 0.9816 & 0.0501 & 0.0929 & 0.9792 & 0.0550 & 0.0725 \\
\hline & 5 & 0.9988 & 0.0120 & 0.0107 & 0.9991 & 0.0111 & 0.0044 & 0.9996 & 0.0076 & 0.0013 \\
\hline & 6 & 0.9802 & 0.0488 & 0.1810 & 0.9710 & 0.0620 & 0.1462 & 0.9679 & 0.0669 & 0.1120 \\
\hline & 7 & 0.9977 & 0.0168 & 0.0212 & 0.9985 & 0.0143 & 0.0075 & 0.9992 & 0.0107 & 0.0028 \\
\hline & 8 & 0.9873 & 0.0396 & 0.1158 & 0.9868 & 0.0430 & 0.0666 & 0.9870 & 0.0445 & 0.0455 \\
\hline & 9 & 0.9852 & 0.0425 & 0.1357 & 0.9849 & 0.0454 & 0.0761 & 0.9856 & 0.0458 & 0.0503 \\
\hline & 10 & 0.8957 & 0.1120 & 0.9540 & 0.8837 & 0.1243 & 0.5867 & 0.8785 & 0.1303 & 0.4242 \\
\hline & 11 & 0.9852 & 0.0425 & 0.1354 & 0.9853 & 0.0448 & 0.0742 & 0.9856 & 0.0457 & 0.0501 \\
\hline \multirow{11}{*}{$\begin{array}{l}\text { Conventional } \\
\text { red pepper }\end{array}$} & 1 & 0.9008 & 0.1100 & 1.0286 & 0.8866 & 0.1215 & 0.6051 & 0.8841 & 0.1254 & 0.4249 \\
\hline & 2 & 0.9972 & 0.0185 & 0.0288 & 0.9984 & 0.0147 & 0.0086 & 0.9993 & 0.0100 & 0.0026 \\
\hline & 3 & 0.9387 & 0.0870 & 0.6359 & 0.9286 & 0.0976 & 0.3809 & 0.9255 & 0.1025 & 0.2732 \\
\hline & 4 & 0.9826 & 0.0467 & 0.1808 & 0.9799 & 0.0524 & 0.1071 & 0.9768 & 0.0583 & 0.0850 \\
\hline & 5 & 0.9986 & 0.0135 & 0.0148 & 0.9990 & 0.0117 & 0.0052 & 0.9996 & 0.0081 & 0.0016 \\
\hline & 6 & 0.9750 & 0.0555 & 0.2589 & 0.9693 & 0.0640 & 0.1637 & 0.9653 & 0.0699 & 0.1270 \\
\hline & 7 & 0.9981 & 0.0155 & 0.0200 & 0.9986 & 0.0139 & 0.0075 & 0.9992 & 0.0107 & 0.0028 \\
\hline & 8 & 0.9832 & 0.0460 & 0.1738 & 0.9804 & 0.0525 & 0.1047 & 0.9772 & 0.0590 & 0.0836 \\
\hline & 9 & 0.9862 & 0.0416 & 0.1434 & 0.9850 & 0.0453 & 0.0799 & 0.9867 & 0.0442 & 0.0488 \\
\hline & 10 & 0.8998 & 0.1112 & 1.0386 & 0.8857 & 0.1235 & 0.6103 & 0.8824 & 0.1287 & 0.4309 \\
\hline & 11 & 0.9861 & 0.0416 & 0.1436 & 0.9854 & 0.0447 & 0.0780 & 0.9867 & 0.0442 & 0.0488 \\
\hline
\end{tabular}


Table 5. Model constants of the Midilli model for the intermittent microwave drying of organic and conventional sweet red pepper slices.

\begin{tabular}{cccccc}
\hline \multirow{2}{*}{ Product Type } & Applied & \multicolumn{4}{c}{ Model Constants } \\
& Power (W) & $\boldsymbol{k}$ & $\boldsymbol{n}$ & $\boldsymbol{a}$ & $\boldsymbol{b}$ \\
\hline \multirow{3}{*}{ Organic red pepper } & 150 & 0.00096 & 1.8842 & 0.9807 & -0.0006 \\
& 300 & 0.00262 & 1.9988 & 0.9970 & -0.0008 \\
& 450 & 0.00416 & 2.1235 & 0.9903 & -0.0007 \\
\hline \multirow{3}{*}{ Conventional red pepper } & 150 & 0.0007 & 1.9620 & 0.9746 & -0.0003 \\
& 300 & 0.0026 & 1.9880 & 0.9928 & -0.0007 \\
& 450 & 0.00415 & 2.1370 & 0.9875 & -0.0004 \\
\hline
\end{tabular}
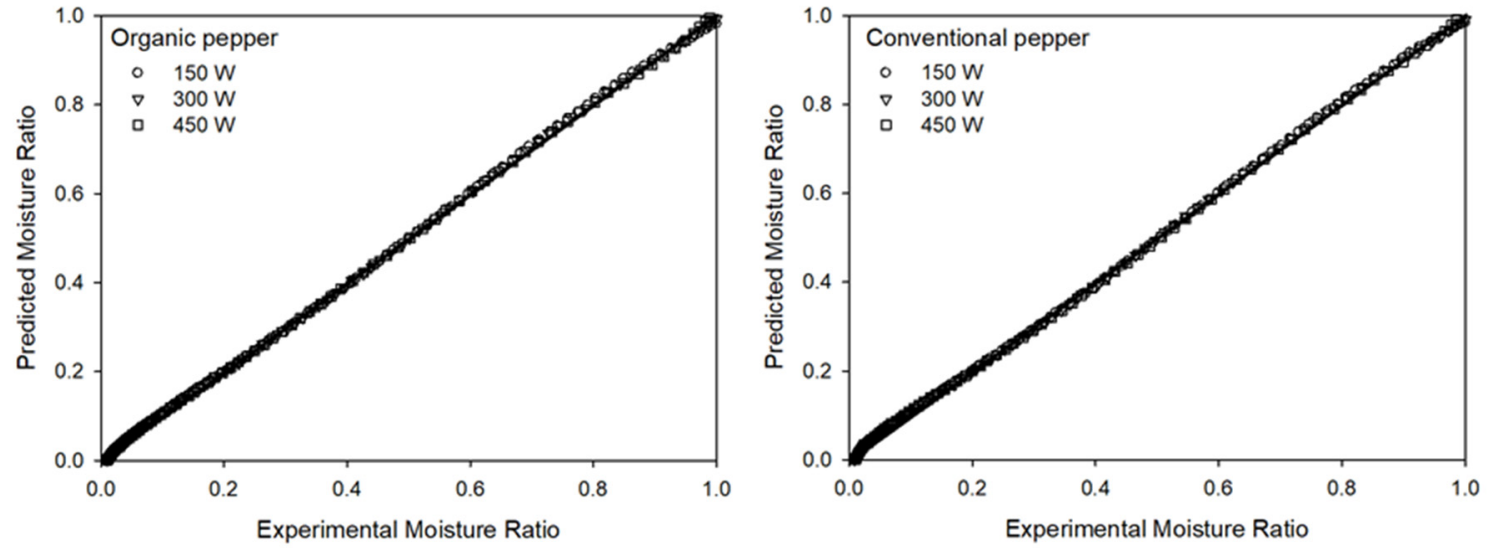

Figure 4. Experimental vs. predicted moisture ratios for different applied intermittent microwave drying powers for organic and conventional sweet red pepper samples.

\subsection{Effective Moisture Diffusivity $\left(D_{\text {eff }}\right)$ and Activation Energy $\left(E_{a}\right)$}

The effective moisture diffusivity $\left(D_{\text {eff }}\right)$ and activation energy $\left(E_{a}\right)$ values for the organic and conventional sweet red pepper shreds dried with three different applied intermittent microwave powers were given in Table 6 . It was seen that increasing the applied microwave power increased the $D_{\text {eff }}$ values considerably. Higher microwave powers speed up the water molecules and elevate the vapor pressure inside the product to evaporate faster and hence, provide more rapid decrease in the moisture content corresponding to higher values of $D_{\text {eff }}$ [47-49]. Depending on the applied microwave power, the $D_{\text {eff }}$ values of organic and conventional pepper shreds ranged from $59.69 \times 10^{-10}$ to $182.01 \times 10^{-10} \mathrm{~m}^{2} \mathrm{~s}^{-1}$ and from $59.11 \times 10^{-10}$ to $181.01 \times 10^{-10} \mathrm{~m}^{2} \mathrm{~s}^{-1}$, respectively (Table 6). No distinct difference was observed between the $D_{\text {eff }}$ values of organic pepper and conventional pepper shreds dried at 150, 300 and $450 \mathrm{~W}$ applied microwave powers.

Table 6. Effective moisture diffusion $\left(D_{\text {eff }}\right)$ coefficients and equations for different applied intermittent microwave powers applied to organic and conventional sweet red peppers.

\begin{tabular}{|c|c|c|c|c|c|}
\hline Product & $\begin{array}{c}\text { Applied } \\
\text { Microwave } \\
\text { Power (W) }\end{array}$ & $\begin{array}{c}D_{0} \\
\left(\times 10^{-8} \mathrm{~m}^{2} \mathrm{~s}^{-1}\right)\end{array}$ & $\begin{array}{c}D_{\text {eff }} \\
\left(\times 10^{-9} \mathrm{~m}^{2} \mathrm{~s}^{-1}\right)\end{array}$ & Linear Equation & $\mathbf{R}^{2}$ \\
\hline \multirow{3}{*}{$\begin{array}{l}\text { Organic } \\
\text { red pepper }\end{array}$} & 150 & \multirow{3}{*}{2.97} & 5.97 & $y=-0.001020 x+0.829988$ & 0.897 \\
\hline & 300 & & 12.35 & $y=-0.002111 x+0.880460$ & 0.904 \\
\hline & 450 & & 18.20 & $y=-0.003110 x+0.895263$ & 0.902 \\
\hline \multirow{3}{*}{$\begin{array}{l}\text { Conventional } \\
\text { red pepper }\end{array}$} & 150 & \multirow{3}{*}{2.97} & 5.91 & $y=-0.001010 x+0.822107$ & 0.924 \\
\hline & 300 & & 12.32 & $y=-0.002105 x+0.912855$ & 0.911 \\
\hline & 450 & & 18.10 & $y=-0.003093 x+0.850155$ & 0.919 \\
\hline
\end{tabular}


The $D_{\text {eff }}$ values established in this work were within the range from $10^{-11}$ to $10^{-9} \mathrm{~m}^{2} \mathrm{~s}^{-1}$ for various biological materials [50,51], very similar [48] and lower [13,52-54] than that of the red or green peppers reported by several authors (Table 7). The variations could be due to differences in the drying conditions and physico-chemical properties of dried materials such as cultivar, composition, slice thickness and stage of ripening [55].

Table 7. Effective moisture diffusivities $\left(D_{\text {eff }}\right)$ and activation energies $\left(E_{a}\right)$ of peppers dried by intermittent microwave as compared to the values in previous studies.

\begin{tabular}{|c|c|c|c|c|}
\hline Products & $\begin{array}{l}\text { Applied Microwave } \\
\text { Power (W) }\end{array}$ & $\begin{array}{c}D_{\text {eff }} \\
\left(\times 10^{-9} \mathrm{~m}^{2} \mathrm{~s}^{-1}\right)\end{array}$ & $\frac{E_{a}}{\left(W g^{-1}\right)}$ & Reference \\
\hline Organic red pepper-shreds & $150-450$ & $5.97-18.20$ & 1.62 & Present study \\
\hline $\begin{array}{l}\text { Conventional red } \\
\text { pepper-shreds }\end{array}$ & $150-450$ & 5.91-18.10 & 1.63 & Present study \\
\hline Red pepper-slice & $210-700$ & $55.97-87.39$ & - & [13] \\
\hline Red pepper-slice & $1050-2100$ & $776-4950$ & $236.2-496.2$ & [53] \\
\hline $\begin{array}{c}\text { Green bell pepper-slice } \\
\text { (200-600 mm Hg vacuum) }\end{array}$ & $100-300$ & $342.1-6597.6$ & 15.0 & [52] \\
\hline Green pepper-half & $180-720$ & $6.25-34.45$ & - & [48] \\
\hline Green pepper, half & $180-540$ & $83.15-236.3$ & 14.2 & {$[54]$} \\
\hline
\end{tabular}

The pre-exponential factor of the Arrhenius equation $\left(D_{0}\right)$ explaining moisture diffusivity when temperature goes to infinity [56] was found to be the same for both product types (Table 6). The same trend was determined for the activation energy $\left(\mathrm{E}_{\mathrm{a}}\right)$ values, which were computed from the slope of the Equation (6) by plotting $\ln \left(\mathrm{D}_{\text {eff }}\right)$ against $\mathrm{m} / \mathrm{P}_{\mathrm{a}}$. The plots showed straight lines for the studied applied power range, which indicated Arrhenius dependence (Figure 5). Thus, the $E_{a}$ values established from the slope of these lines were 1.62 and $1.63 \mathrm{~W} \mathrm{~g}^{-1}$ for the organic and conventional sweet red pepper samples, respectively (Table 7).
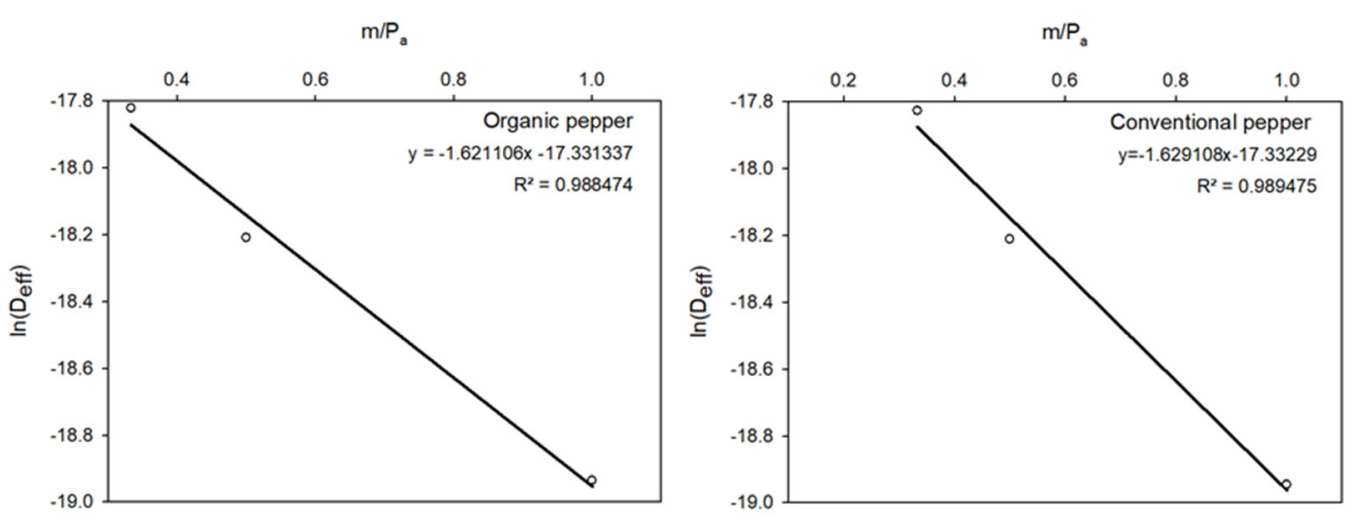

Figure 5. Arrhenius plot for the calculation of the activation energy of organic and conventional red peppers.

The $E_{a}$ value determines the sensitivity of diffusivity against temperature. Higher $E_{a}$ values indicate higher sensitivity of the diffusivity to the temperature [56]. The similarity between the $E_{a}$ values of organic and conventional peppers signifies that organic or conventional growing practice did not significantly alter the structural properties of the sweet red pepper samples. Furthermore, both the organic and conventional pepper shreds showed the same resistance to the moisture transported in the drying material as a result of intermittent microwave drying. The drying kinetic profiles and the calculated $D_{\text {eff }}$ values given above strongly support this statement. The $E_{a}$ values of the red pepper shreds obtained in the current study were similar [52,54] and much lower [53] as compared to the $E_{a}$ values reported by several authors for green and red peppers (Table 7). Differences can be attributed to 
different factors including cultivar, physico-chemical properties of dried material, composition, design features of drying equipment, microwave power level, slice thickness, growing conditions, ripening stage, etc.

\subsection{Influence of Applied Microwave Power on the Color of Powdered Red Pepper Samples}

The relations between the applied intermittent microwave power and color parameters of fresh and dried red pepper shreds were given in Table 8 . The $L^{*}$ and $b^{*}$ values of the organic and conventional fresh samples did not show any statistically significant difference. However, redness $\left(a^{*}\right)$ and $a^{*} / b^{*}$ ratios of fresh organic and conventional samples were different $(p<0.05)$, which signifies that the color of fresh conventional samples was deeper in red as compared to the organic samples (Table 8). Thus, the differences between organic and conventional samples were due to a difference in $\mathrm{a}^{*}$ parameter from the fresh samples.

The $L^{*}$ value of the dried and powdered red peppers was significantly higher than that of the fresh peppers $(p<0.05)$. It was observed that, as compared to fresh product, the redness values of dried peppers increased first and then decreased depending on the increase in applied microwave power. In terms of microwave treatments, $450 \mathrm{~W}$ always showed lower $\mathrm{a}^{*}$ values, followed by $300 \mathrm{~W}$, while $150 \mathrm{~W}$ demonstrated higher values of $\mathrm{a}^{*}$ and $\mathrm{a}^{*} / \mathrm{b}^{*}$ for organic and conventional products as compared to other microwave powers. The redness $\left(\mathrm{a}^{*}\right)$ values of organic and conventional red peppers dried at $150 \mathrm{~W}$ microwave power were noticeably higher than that of fresh red peppers $(p<0.05)$. Beside this, no significant difference was determined between the $\mathrm{a}^{*}$ values of fresh and dried organic pepper shreds dried at $300 \mathrm{~W}$ power level.

Commonly used quality criteria for dried red pepper was red color intensity $[57,58]$, which comes from ketocarotenoids, capsanthin and capsorubin. Moreover, some researchers reported that the dried red peppers having a higher ratio of redness to yellowness $\left(a^{*} / b^{*}\right)$ were considered as more preferable [59]. The $\mathrm{a}^{*} / \mathrm{b}^{*}$ values were found to be lower in the current study in both fresh and dried products as compared to the findings of Ergunes and Tarhan [59] (who reported up to 3.93) and this difference could be due to some factors such as pepper type, production method, drying technique, and maturity level, etc. It is clear that the $L^{*}$ values of both organic and conventional fresh samples were significantly enhanced after microwave drying process in the present study $(p<0.05)$.

Compared to the fresh product color values, it was determined that the change in the redness values remained at a limited level, whereas the yellowness values increased to a higher extent. The highest color difference values $\left(\Delta \mathrm{L}^{*}, \Delta \mathrm{a}^{*}, \Delta \mathrm{b}^{*}\right.$ and $\left.\Delta \mathrm{E}^{*}\right)$ were obtained at lower microwave power levels (Table 8). On the other hand, microwave drying at 150 and $300 \mathrm{~W}$ for organic peppers and at $150 \mathrm{~W}$ for conventional red peppers yielded the highest $\Delta \mathrm{L}^{*}, \Delta \mathrm{a}^{*}$ and $\mathrm{a}^{*} / \mathrm{b}^{*}$ values. This implies that these pepper powders were deeper and brighter in red color (Table 8). Hence, intermittent microwave drying at 150 and $300 \mathrm{~W}$ for organic peppers and at $150 \mathrm{~W}$ for conventional red peppers can be evaluated as the most suitable drying applications because these treatments gave brighter and redder pepper powders as compared to fresh peppers. 
Table 8. Color parameters of fresh and intermittent microwave-dried and powdered organic and conventional red pepper samples $(n=9 ;$ mean \pm std. dev.).

\begin{tabular}{|c|c|c|c|c|c|c|c|c|c|}
\hline \multirow{2}{*}{$\begin{array}{c}\text { Product } \\
\text { Type }\end{array}$} & \multirow{2}{*}{$\begin{array}{l}\text { Applied Microwave } \\
\text { Power (W) }\end{array}$} & \multicolumn{8}{|c|}{ Color Parameters * } \\
\hline & & $L^{*}$ & $a^{*}$ & $\mathbf{b}^{*}$ & $a^{*} / b^{*}$ & $\Delta \mathrm{L}^{*}$ & $\Delta \mathbf{a}^{*}$ & $\Delta \mathbf{b}^{*}$ & $\Delta \mathrm{E}$ \\
\hline \multirow{4}{*}{$\begin{array}{l}\text { Organic red } \\
\text { pepper }\end{array}$} & Fresh & $30.93 \pm 0.02^{a}$ & $24.1 \pm 0.03^{c, d}$ & $22.34 \pm 0.06^{\mathrm{a}}$ & $1.08 \pm 0.00^{\mathrm{e}}$ & - & - & - & - \\
\hline & 150 & $55.66 \pm 0.86^{\mathrm{e}}$ & $27.54 \pm 0.97^{f}$ & $37.58 \pm 0.91^{\mathrm{f}}$ & $0.73 \pm 0.04^{d}$ & $24.73 \pm 0.86^{c}$ & $3.43 \pm 0.97^{\mathrm{e}}$ & $15.23 \pm 0.91^{\mathrm{d}}$ & $29.27 \pm 1.10^{d}$ \\
\hline & 300 & $53.51 \pm 0.91^{\mathrm{d}}$ & $24.86 \pm 0.98^{\mathrm{d}, \mathrm{e}}$ & $35.22 \pm 0.94^{\mathrm{d}}$ & $0.71 \pm 0.02^{c}$ & $22.58 \pm 0.91^{b}$ & $0.75 \pm 0.98^{d}$ & $12.87 \pm 0.94^{c}$ & $26.03 \pm 1.20^{c}$ \\
\hline & 450 & $50.81 \pm 1.16^{\mathrm{b}}$ & $19.73 \pm 1.48^{\mathrm{b}}$ & $31.71 \pm 1.34^{c}$ & $0.62 \pm 0.02^{a}$ & $19.88 \pm 1.16^{\mathrm{a}}$ & $-4.37 \pm 1.48^{b}$ & $9.36 \pm 1.34^{b}$ & $22.48 \pm 1.24^{\mathrm{a}}$ \\
\hline \multirow{4}{*}{$\begin{array}{l}\text { Conventional } \\
\text { red pepper }\end{array}$} & Fresh & $30.18 \pm 0.02^{a}$ & $25.29 \pm 0.04^{\mathrm{e}}$ & $21.81 \pm 0.06^{\mathrm{a}}$ & $1.16 \pm 0.00^{\mathrm{f}}$ & - & - & - & - \\
\hline & 150 & $59.18 \pm 0.97^{\mathrm{f}}$ & $27.62 \pm 0.94^{f}$ & $37.06 \pm 0.85^{\mathrm{e}, \mathrm{f}}$ & $0.75 \pm 0.04^{\mathrm{d}}$ & $29.00 \pm 0.97^{\mathrm{d}}$ & $2.32 \pm 0.94 \mathrm{e}^{\mathrm{e}}$ & $15.263 \pm 0.85^{d}$ & $32.86 \pm 1.19^{\mathrm{e}}$ \\
\hline & 300 & $58.53 \pm 0.87^{f}$ & $23.73 \pm 0.75^{c}$ & $36.25 \pm 0.79 \mathrm{e}$ & $0.66 \pm 0.02^{b}$ & $28.35 \pm 0.87^{d}$ & $-1.56 \pm 0.75^{c}$ & $14.44 \pm 0.79^{\mathrm{d}}$ & $31.86 \pm 1.00^{\mathrm{e}}$ \\
\hline & 450 & $51.81 \pm 1.17^{c}$ & $18.23 \pm 1.38^{a}$ & $29.51 \pm 1.47^{b}$ & $0.62 \pm 0.03^{a}$ & $21.62 \pm 1.17^{b}$ & $-7.06 \pm 1.38^{a}$ & $7.70 \pm 1.47^{\mathrm{a}}$ & $24.10 \pm 1.17^{b}$ \\
\hline
\end{tabular}




\section{Conclusions}

The results revealed that drying of the conventional pepper shreds lasted 1 to 8 min longer as compared to organic peppers. Except $150 \mathrm{~W}\left(1.0 \mathrm{Wg}^{-1}\right)$, no substantial difference was determined between the drying times of organic and conventional red pepper samples dried at $300\left(2.0 \mathrm{Wg}^{-1}\right)$ and $450 \mathrm{~W}\left(3.0 \mathrm{Wg}^{-1}\right)$ power levels.

The Midilli model provided the best fit for all drying data points for both organic and conventional peppers.

Depending on the applied microwave power, the $\mathrm{D}_{\text {eff }}$ values of organic and conventional red pepper shreds ranged from $59.69 \times 10^{-10}$ to $182.01 \times 10^{-10} \mathrm{~m}^{2} \mathrm{~s}^{-1}$ and from $59.11 \times 10^{-10}$ to $181.01 \times 10^{-10} \mathrm{~m}^{2} \mathrm{~s}^{-1}$, respectively. No distinct difference was found between the $D_{\text {eff }}$ values of organic and conventional pepper shreds dried at 150,300 and $450 \mathrm{~W}$ applied microwave powers. The activation energy $\left(E_{a}\right)$ was found to be 1.62 and $1.63 \mathrm{~W} \mathrm{~g}^{-1}$ for the organic and conventional samples. Both the pre-exponential factor of the Arrhenius equation $\left(D_{0}\right)$ and activation energy $\left(E_{a}\right)$ values were found as almost identical for both product types. Consequently, close similarity among the characteristics drying curves, $D_{\text {eff }}$ and $E_{a}$ values signifies that organic or conventional growing practice did not significantly alter the structural properties of the sweet red pepper samples. Both the organic and conventional pepper shreds showed the same resistance to the moisture transported in the pepper samples as a result of intermittent microwave drying (IMD).

The color of fresh conventional red pepper samples was deeper in red as compared to the organic samples. IMD at $150\left(1.0 \mathrm{Wg}^{-1}\right)$ and $300 \mathrm{~W}\left(2.0 \mathrm{Wg}^{-1}\right)$ for organic red peppers and at $150 \mathrm{~W}\left(1.0 \mathrm{Wg}^{-1}\right)$ for conventional peppers yielded the highest $\Delta \mathrm{L}^{*}, \Delta \mathrm{a}^{*}$ and $\mathrm{a}^{*} / \mathrm{b}^{*}$ values, which implies that these pepper powders were deeper and brighter in red color. Hence, IMD at 150 and $300 \mathrm{~W}$ for organic red peppers and $150 \mathrm{~W}$ for conventional red peppers can be evaluated as the suitable drying applications, as these treatments gave brighter and redder pepper powders as compared to fresh peppers.

Due to the increasing demand for organic products, future studies are needed on the drying kinetics, color parameters, aroma profiles and sensory attributes of other organic products as compared to the conventional products.

Author Contributions: A.A., Y.S. and M.K. conceptualized the research; A.A. and M.K. designed the experiments and collected experimental data; A.A. and Y.S. carried out the data analysis; Y.S. and M.K. wrote the manuscript; all authors edited and revised the manuscript. All authors have read and agreed to the published version of the manuscript.

Funding: This research received no external funding.

Acknowledgments: The authors thank Yunus Emre Sekerli for his assistance in experimental data collection.

Conflicts of Interest: The authors declare no conflict of interest.

\section{References}

1. TurkStat. Organic Crop Production Statistics; Turkish Statistical Institute (TurkStat): Ankara, Turkey, 2018.

2. Lernoud, J.; Willer, H. Organic Agriculture Worldwide: Key Results from the FiBL Survey on Organic Agriculture Worldwide, Part 3: Organic Agriculture in the Regions; Research Institute of Organic Agric (FIBL): Frick, Switzerland, 2019.

3. Bickel, R.; Rossier, R. Sustainability and Quality of Organic Food; Research Institute of Organic Agriculture (FiBL) and the Organic Research Centre, Elm Farm (ORC): Frick, Switzerland, 2015.

4. Winter, C.K.; Davis, S.F. Organic foods. J. Food Sci. 2006, 71, R117-R124. [CrossRef]

5. Brandt, K.; Leifert, C.; Sanderson, R.; Seal, C.J. Agroecosystem management and nutritional quality of plant foods: The case of organic fruits and vegetables. Crit. Rev. Plant. Sci. 2011, 30, 177-197. [CrossRef]

6. Gomiero, T. Food quality assessment in organic vs. conventional agricultural produce: Findings and issues. App. Soil Ecol. 2018, 123, 714-728. [CrossRef]

7. Moraes, I.C.F.; Sobral, P.J.D.A.; Branco, I.G.; Ré, T.B.; Gomide, C.A. Dehydration of “dedo de moça” pepper: Kinetics and phytochemical concentration. Food Sci. Technol. 2013, 33, 134-141. [CrossRef] 
8. Soysal, Y.; Ayhan, Z.; Eştürk, O.; Arikan, M.F. Intermittent microwave-convective drying of red pepper: Drying kinetics, physical (colour and texture) and sensory quality. Biosyst. Eng. 2009, 103, 455-463. [CrossRef]

9. FAO. FAOSTAT Crop Production Statistics Database; Food and Agriculture Organization (FAO) of the United Nations: Rome, Italy, 2009.

10. TMAF. Organic Agricultural Production Data; Turkish Ministry of Agriculture and Forestry (TMAF): Ankara, Turkey, 2019.

11. Chou, S.K.; Chua, K.J. New hybrid drying technologies for heat sensitive foodstuffs. Trends Food Sci. Technol. 2001, 12, 359-369. [CrossRef]

12. Soysal, Y.; Oztekin, S.; Eren, O. Microwave drying of parsley: Modelling, kinetics, and energy aspects. Biosyst. Eng. 2006, 93, 403-413. [CrossRef]

13. Arslan, D.; Ozcan, M.M. Dehydration of red bell-pepper (Capsicum annuum L.): Change in drying behavior, colour and antioxidant content. Food Bioprod. Proc. 2011, 89, 504-513. [CrossRef]

14. Zhang, M.; Tang, J.; Mujumdar, A.S.; Wang, S. Trends in microwave-related drying of fruits and vegetables. Trends Food Sci. Technol. 2006, 17, 524-534. [CrossRef]

15. Dev, S.R.S.; Geetha, P.; Orsat, V.; Gariépy, Y.; Raghavan, G.S.V. Effects of microwave-assisted hot air drying and conventional hot air drying on the drying kinetics, color, rehydration, and volatiles of Moringa oleifera. Dry. Technol. 2011, 29, 1452-1458. [CrossRef]

16. Kumar, C.; Karim, M.A. Microwave-convective drying of food materials: A critical review. Crit. Rev. Food Sci. Nutr. 2019, 59, 379-394. [CrossRef]

17. Ekezie, F.G.C.; Sun, D.W.; Han, Z.; Cheng, J.H. Microwave-assisted food processing technologies for enhancing product quality and process efficiency: A review of recent developments. Trends Food Sci. Technol. 2017, 67, 58-69. [CrossRef]

18. Pham, N.D.; Khan, M.I.H.; Joardder, M.U.H.; Rahman, M.M.; Mahiuddin, M.; Abesinghea, A.M.N.; Karim, M.A. Quality of plant-based food materials and its prediction during intermittent drying. Crit. Rev. Food Sci. Nutr. 2019, 59, 1197-1211. [CrossRef]

19. Gunasekaran, S. Pulsed microwave-vacuum drying of food materials. Dry. Technol. 1999, 17, 395-412. [CrossRef]

20. Esturk, O.; Arslan, M.; Soysal, Y.; Üremiş, İ.; Ayhan, Z. Drying of sage (Salvia officinalis L.) inflorescences by intermittent and continuous microwave-convective air combination. Res. Crops 2011, 12, 607-615.

21. Botha, G.E.; Oliveira, J.C.; Ahrné, L. Microwave assisted air drying of osmotically treated pineapple with variable power programmes. J. Food Eng. 2012, 108, 304-311. [CrossRef]

22. Esturk, O. Intermittent and continuous microwave-convective air-drying characteristics of sage (Salvia officinalis) leaves. Food Bioprocess Technol. 2012, 5, 1664-1673. [CrossRef]

23. Changrue, V. Hybrid (Osmotic, Microwave-Vacuum) Drying of Strawberries and Carrots. Doctoral Dissertation, McGill University, McGill, QC, Canada, 2006.

24. Baini, R.; Langrish, T.A.G. Choosing an appropriate drying model for intermittent and continuous drying of bananas. J. Food Eng. 2007, 79, 330-343. [CrossRef]

25. Keskin, M.; Soysal, Y.; Arslan, A.; Sekerli, Y.E.; Celiktas, N. Predicting Drying Temperature of Infrared-Dried Pepper Powders Using FT-NIRS and Chromameter. In Proceedings of the International Conference on Energy Research (ENRES2018), Alanya, Turkey, 1-2 November 2018; pp. 305-319.

26. Arikan, M.F.; Ayhan, Z.; Soysal, Y.; Esturk, O. Drying characteristics and quality parameters of microwave-dried grated carrots. Food Bioprocess Technol. 2012, 5, 3217-3229. [CrossRef]

27. Soysal, Y.; Arslan, M.; Keskin, M. Intermittent microwave-convective air drying of oregano. Food Sci. Technol. Int. 2009, 15, 397-406. [CrossRef]

28. Sharifian, F.; Motlagh, A.M.; Nikbakht, A.M. Pulsed microwave drying kinetics of fig fruit ('Ficus carica'L.). Aust. J. Crop Sci. 2012, 6, 1441.

29. Junqueira, J.R.D.J.; Corrêa, J.L.G.; Ernesto, D.B. Microwave, convective, and intermittent microwaveconvective drying of pulsed vacuum osmodehydrated pumpkin slices. J. Food Proc. Pres. 2017, 41, e13250. [CrossRef]

30. Dehghannya, J.; Farshad, P.; Heshmati, M.K. Three-stage hybrid osmotic-intermittent microwave-convective drying of apple at low temperature and short time. Dry. Technol. 2018, 36, 1982-2005. [CrossRef]

31. Asami, D.K.; Hong, Y.J.; Barrett, D.M.; Mitchell, A.E. Comparison of the total phenolic and ascorbic acid content of freeze-dried and air-dried marionberry, strawberry, and corn grown using conventional, organic, and sustainable agricultural practices. J. Agric. Food Chem. 2003, 51, 1237-1241. [CrossRef] 
32. Sablani, S.S.; Andrews, P.K.; Davies, N.M.; Walters, T.; Saez, H.; Bastarrachea, L. Effects of air and freeze drying on phytochemical content of conventional and organic berries. Dry. Technol. 2011, 29, 205-216. [CrossRef]

33. Buffler, C.R. Microwave Cooking and Processing: Engineering Fundamentals for the Food Scientist; Avi Book: New York, NY, USA, 1993; pp. 39-54.

34. Maskan, M. Microwave/air and microwave finish drying of banana. J. Food Eng. 2000, 44, 71-78. [CrossRef]

35. Ertekin, C.; Yaldiz, O. Drying of eggplant and selection of a suitable thin layer drying model. J. Food Eng. 2004, 63, 349-359. [CrossRef]

36. Diamente, L.M.; Munro, P.A. Mathematical modeling of the thin layer solar drying of sweet potato slices. Solar Energy 1993, 51, 271-276. [CrossRef]

37. Yagcioglu, A.; Degirmencioglu, A.; Cagatay, F. Drying characteristics of laurel leaves under different drying conditions. In Proceedings of the 7th International Congress on Agricultural Mechanization and Energy in Agricultural, Adana, Turkey, 26-27 May 1999; pp. 565-569.

38. Midilli, A.; Kucuk, H.; Yapar, Z. A new model for single-layer drying. Dry. Technol. 2002, 20, $1503-1513$. [CrossRef]

39. Wang, C.Y.; Singh, R.P. A Single Layer Drying Equation for Rough Rice; American Society of Agricultural Engineers (ASAE): St. Joseph, MI, USA, 1978; p. 3001.

40. Jain, D.; Pathare, P.B. Selection and evaluation of thin layer drying models for infrared radiative and convective drying of onion slices. Biosyst. Eng. 2004, 89, 289-296. [CrossRef]

41. Verma, L.R.; Bucklin, R.A.; Endan, J.B.; Wratten, F.T. Effects of drying air parameters on rice drying models. Trans. ASAE 1985, 28, 296-301. [CrossRef]

42. Crank, J. Mathematics of Diffusion, 2nd ed.; Oxford University Press: London, UK, 1975; p. 414.

43. Wang, Z.; Sun, J.; Chen, F.; Liao, X.; Hu, X. Mathematical modelling on thin layer microwave drying of apple pomace with and without hot air pre-drying. J. Food Eng. 2007, 80, 536-544. [CrossRef]

44. Dadali, G.; Demirhan, E.; Ozbek, B. Microwave heat treatment of spinach: Drying kinetics and effective moisture diffusivity. Dry. Technol. 2007, 25, 1703-1712. [CrossRef]

45. Beaudry, C.; Raghavan, G.S.V.; Rennie, T.J. Microwave finish drying of osmotically dehydrated cranberries. Dry. Technol. 2003, 21, 1797-1810. [CrossRef]

46. Cui, Z.W.; Xu, S.Y.; Sun, D.W. Microwave-vacuum drying kinetics of carrot slices. J. Food Eng. 2004, 65, 157-164. [CrossRef]

47. Thuwapanichayanan, R.; Prachayawarakorn, S.; Kunwisawa, J.; Soponronnarit, S. Determination of effective moisture diffusivity and assessment of quality attributes of banana slices during drying. LWT 2011, 44, 1502-1510. [CrossRef]

48. Darvishi, H.; Khoshtaghaza, M.H.; Najafi, G.; Nargesi, F. Mathematical modeling of green pepper drying in microwave-convective dryer. J. Agric. Sci. Technol. 2013, 15, 457-465.

49. Soysal, Y.; Keskin, M.; Arslan, A.; Sekerli, Y.E. Infrared drying characteristics of pepper at different maturity stages. In Proceedings of the Int. Conf. on Energy Research (ENRES 2018), Alanya, Turkey, 1-2 November 2018.

50. Madamba, P.S.; Driscoll, R.H.; Buckle, K.A. The thin-layer drying characteristics of garlic slices. J. Food Eng. 1996, 29, 75-97. [CrossRef]

51. Kumar, N.; Sarkar, B.C.; Sharma, H.K. Effect of air velocity on kinetics of thin layer carrot pomace drying. Food Sci. Technol. Int. 2011, 17, 459-469. [CrossRef] [PubMed]

52. Kumar, V.; Shrivastava, S.L. Vacuum-assisted microwave drying characteristics of green bell pepper. Int. J. Food Stud. 2017, 6. [CrossRef]

53. Celen, S.; Akyol, U.; Moralar, A. Determination of the effective moisture diffusivity of red pepper in a microwave conveyor dryer. Termotehnica Supl. 2016, 1, 27-31.

54. Darvishi, H.; Asl, A.R.; Asghari, A.; Azadbakht, M.; Najafi, G.; Khodaei, J. Study of the drying kinetics of pepper. J. Saudi Soc. Agric. Sci. 2014, 13, 130-138. [CrossRef]

55. Deng, L.Z.; Yang, X.H.; Mujumdar, A.S.; Zhao, J.H.; Qian, D.W.; Zhang, J.W.; Gao, Z.J.; Xiao, H.W. Red pepper (Capsicum annuum L.) drying: Effects of different drying methods on drying kinetics, physicochemical properties, antioxidant capacity, and microstructure. Dry. Technol. 2018, 36, 893-907. [CrossRef]

56. Turhan, M.; Turhan, K.N.; Sahbaz, F. Drying kinetics of red pepper. J. Food Proc. Preserv. 1997, $21,209-223$. [CrossRef] 
57. Kim, S.; Park, J.; Hwang, I.K. Composition of main carotenoids in Korean red pepper (capsicum annuum, L) and changes of pigment stability during the drying and storage process. J. Food Sci. 2004, 69, FCT39-FCT44. [CrossRef]

58. Topuz, A.; Dincer, C.; Özdemir, K.S.; Feng, H.; Kushad, M. Influence of different drying methods on carotenoids and capsaicinoids of paprika (Cv., Jalapeno). Food Chem. 2011, 129, 860-865. [CrossRef]

59. Ergunes, G.; Tarhan, S. Color retention of red peppers by chemical pretreatments during greenhouse and open sun drying. J. Food Eng. 2006, 76, 446-452. [CrossRef]

(C) 2020 by the authors. Licensee MDPI, Basel, Switzerland. This article is an open access article distributed under the terms and conditions of the Creative Commons Attribution (CC BY) license (http://creativecommons.org/licenses/by/4.0/). 